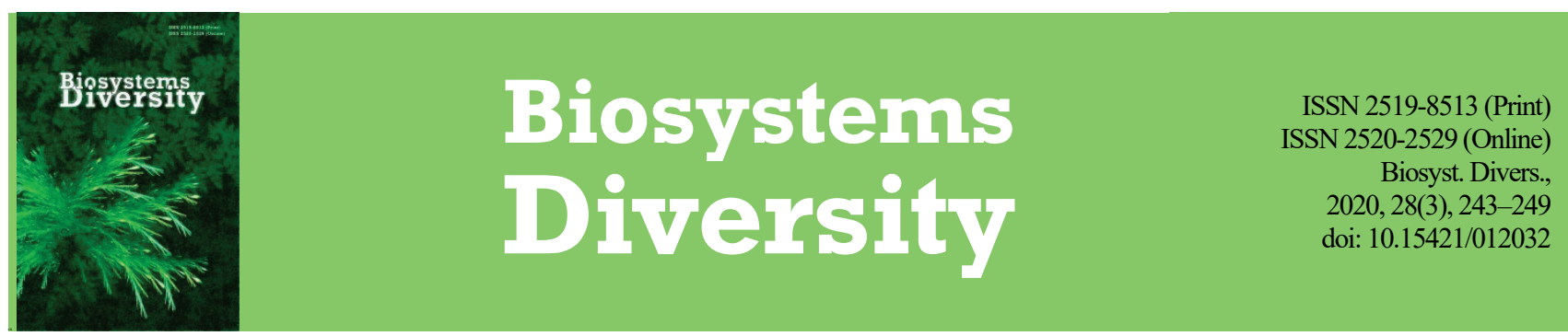

\title{
Peculiarities of the development and seasonal dynamics of the activity of epigean beetles of the Polyphaga suborder (Coleoptera) in fields of winter wheat in the conditions of Southern Ukraine
}

\author{
J. A. Batschynskaja, T. E. Komisova, I. O. Lykova \\ H. S. Skovoroda Kharkiv National Pedagogical University, Kharkiv, Ukraine
}

Article info

Received 19.07.2020

Received in revised form 27.08.2020

Accepted 29.08.2020

H. S. Skovoroda

Kharkiv National

Pedagogical University

Alchevskych st., 29

Kharkiv, 61002, Ukraine

Tel.: + 38-057-700-69-09.

E-mail:

irlyk16@gmail.com

\begin{abstract}
Batschynskaja, J. A., Komisova, T. E., \& Lykova, I. O. (2020). Peculiarities of the development and seasonal dynamics of the activity of epigean beetles of the Polyphaga suborder (Coleoptera) in fields of winter wheat in the conditions of Southern Ukraine. Biosystems Diversity, 28(3), 243-249. doi:10.15421/012032
\end{abstract}

In total, 168 beetle species from 25 families of the suborder Polyphaga have been recorded on winter wheat crops. 116 species (about 20 families) are registered as stratobionts: 14 were dominants, 32 - subdominants and about 70 species were very rare. The main representatives of stratobios were Staphylinidae, Silphidae, Dermestidae, Histeridae, some Elateridae and Scarabaeidae and most Tenebrionidae. Most staphylinids are more numerous in spring (late April - first half of May) and sometimes in summer (especially dominant Tachyporus hypnorum). A high number of Silphidae was noted by mid-May, but decreased in the summer months. Two peaks of abundance are characteristic of Anthicidae, Latridiidae and Cryptophagidae: the smaller in spring (the first half of May) and the maximum in summer (the second half of June- early July). The number of Dermestidae increases gradually from mid-May and reaches maximum from late May to early or mid-June. Among Tenebrionidae, the species of genera Opatrum and Gonocepalum are more numerous in spring than in summer. Crypticus quisquilius were numerous by mid-summer. Among Elateridae, high number of Agriotes sputator was recorded from May to mid-June, and the appearance of Aelosomus rossi was recorded from mid-April, with a peak in the first half of summer. In spring, some Scarabaeidae (some species of Geotrupinae and Pentodon idiota), Histeridae and some species of weevils were more numerous in summer. In years with different meteorological conditions, significant discrepancies were noted in the timing of the rise and fall in the number of many beetles. But smaller differences in the number of specimens are noted between different years in comparision with individual phases of wheat vegetation. Some features of the sex index of beetles (higher during egg laying) and the development of dominant species are briefly considered.

Keywords: polyphagous beetles; stratobios; changes of number; seasons; year; agrocenosis; grain; steppe zone.

\section{Introduction}

The study of specifics of the seasonal changes in the abundance of insects, their mode of life and development in the conditions of agrocenoses is of special importance both for understanding the patterns of the formation of the structure of entomofauna and development of an integrated method of plant protection. One of the dominating orders of insects in fields is Coleoptera, especially the representatives of such a numerous group as the inhabitants of the upper layers of soil and litter - epigeal habitat. Despite the interest continuously shown over 50 years in the entomofauna of agrocenoses, the patterns of seasonal dynamics and development of many coleopterans remains very unevenly studied in Ukraine and elsewhere. Within the group of epigean beetles, the bulk of attention has been paid to one of the largest representatives of this group ground beetles (Carabidae), which have been the focus in most ecologicalfaunistic studies related to the Coleoptera fauna of agrocenoses (Putchkov, 2018; Putchkov et al., 2019). Not much less studied than the ground beetles are rove beetles (Staphylinidae), described in many publications both in general and regarding certain aspects of changes in their abundance in agrocenoses (Soboleva-Dokuchaeva et al., 2002; Guseva \& Koval, 2011, 2015, 2020; Frank \& Reichhart, 2004; Cloyd \& Herrick, 2018; Guseva, 2019). Most other beetles are studied unevenly, usually in an extremely fragmented manner. Some publications nonetheless do focus on the complex of epigean beetles (Hummel et al., 2002; Munteanua et al., 2014; Skoková-Habužstová et al., 2014; Brygadyrenko, 2014, 2016; Belitzkaya, 2015; Gospodarek et al., 2020), including such families as Silphidae and Dermestidae (Růžička, 1994; Pushkin, 1999, 2010). In Ukraine, ecological-faunistic studies of epigean coleopterans have been performed in separate transformed cenoses, including field crops. However, traditionally the ground beetles have received the most attention (Putchkov, 2018). Much less research has been conducted on other families of beetles: skinbeetles and carrion-beetles (Dermestidae, Silphidae) (Putchkov, 1985, 2010), lamellicorn-beetles (Scarabaeidae) (Putchkov et al., 2017), clownbeetles (Histeridae) (Putchkov \& Komaromi, 2018), darkling beetles (Tenebrionidae) (Cherney, 2005), click-beetles (Elateridae) (Dolin, 1982, 1988), weevils (Curculionidae) (Komaromi et al., 2019) and others (Putchkov, 1991; Sumarokov, 2009).

The objective of our study was the peculiarities of the development and patterns of seasonal changes in abundance of the main families of epigean coleopterans of the Polyphaga order in winter wheat (as a model agrocenosis) in various calendar and phenological periods of vegetation of the crop in the conditions of Southern Ukraine.

\section{Materials and methods}

Materials for this work were the authors' collections, as well as collections of beetles kindly given to us for the laboratory studies by Prof. A. V. Putchkov, to whom the authors express sincere gratitude. The beetles were counted in 2008, 2009 and 2011 in winter wheat fields in the steppe zone of Ukraine: Bashtanka Raion, Mykolaiv Oblast. During the studies, we used Barber pit-fall traps (plastic cups of $0.2 \mathrm{~L}$ capacity, filled with $10 \%$ solution of acetic acid). In 2008 and 2009, we examined three fields of wheat in each year (the total area of around $250 \mathrm{ha}$ ), and in 2011 two fields (about 150 ha). In each field, we set 10-20 traps arranged in checkerboard pattern at the same distance one from another. The selection of insects was made with 10-15 days intervals during the period of vege- 
tation of the crop: from late April to mid July and from mid September to mid October. In total, throughout the period of study, 220 counts were made.

The number of beetles caught in a certain period reflected their relative abundance (or dynamic density) which directly depends on the moving activity of beetles (Tikhomirova, 1975). The abundance of the beetles was expressed in catching days, for example individuals captured (on average) in one trap during a day, in 10 traps per day, etc. The main attention was paid to the abundant and common species, i.e. the share of which exceeded $2 \%$ of the total number of coleopterans recorded in separate selections (Komaromi et al., 2018; Putchkov, 2018). The counts were performed not only in calendar, but phenological periods of vegetation of wheat: from the phase of tillering to the phase of wax ripeness.

To study the daily activity of the beetles, in a separate field we set 20 traps, and selected the material after every $3-4 \mathrm{~h}$. The measuring unit of daily activity of beetles was the amount of individuals captured during an hour and was expressed as a percentage of the total number of recorded coleopterans. The counts of daily activity were conducted several times in the period from mid May to mid June, i.e. during the mass activity of most epigean beetles.

The sex index was expressed as the ratio of females to the total number of beetles of each species in a sample. For the count of mature ovarian eggs, we selected no less than 20 females of beetles of a specific species, which we previously intensely moistened in desiccator. Then, the abdomens were separated and boiled in $5 \%$ solution of alkaline $(\mathrm{NaOH}$ or $\mathrm{KOH}$ ), thus achieving the maceration of all the non-chitin tissues, and the eggs mature for laying which were covered with dense chorion were kept inside the abdomen. The abdomen taken out of alkaline and well rinsed with water was dissected with sharp blade or dissecting needle on the pleura. The residuals of the macerated eggs were removed with a brush by rolling the contents of the abdomen on filter paper, and then the eggs were counted using a binocular microscope. The selection of beetles for determining the sex index and counting ovarian eggs was carried out in different calendar periods, usually from the beginning of rise, peak and fall in the number of species.

We identified most of the beetles (using the Guide to Beetles of the European part of the USSR, 1965), but identifications of some species were confirmed by Prof. A. V. Putchkov, Ph.D. A. A. Petrenko and Ph.D. V. Y. Nazarenko (I. I. Schmalhausen Institute of Zoology of National Academy of Sciences of Ukraine).

\section{Results}

In total, in areas sown with winter wheat, we recorded 168 species of beetles, belonging to 25 families of the suborder Polyphaga. Among them, 116 were identified as epigean species, 14 of which were dominant, 32 subdominants, and the remaining beetles (around 70 species) occurred rarely and singularly. The main representatives of epigean beetles were staphylinids (Staphylinidae), carrion-beetles (Silphidae), skin-beetles (Dermestidae), clown-beetles (Histeridae), ant-like flower beetles (Anthicidae), less abundant were minute scavenger-beetles (Latridiidae), silken fungus beetles (Cryptophagidae), some click-beetles (Elateridae), lamellicornbeetles (Scarabaeidae) and most of the darkling beetles (Tenebrionidae). Rarer, were representatives of the families Byrrhidae, Anobiidae, Trogidae, Meloidae and Phalacridae.

The inhabitants of other layers (mainly hortobionts) and randomly captured ones were represented by over 50 species. These were chiefly (Coccinellidae), leaf beetles (Chrysomelidae), most of weevils (Curculionidae), Cantharidae and Melyridae, darkling beetles of subfamily Alleculinae and lamellicorn-beetles of subfamily Melolonthinae.

In the comparative aspect, the species composition recorded in the epigeal habitat of beetles had a lot in common with the data given for the same territory in the report by Puchkov (1991) and presented for Steppe Ukraine in general (Sumarokov, 2009). Below, we present the taxonomic characteristic and tendencies of seasonal fluctuations of the abundance of the dominant families.

Staphylinids (rove beetles) comprised $15-50 \%$ of the abundance of the suborder and were represented by 35 species, of which the only abundant species was Tachyporum hypnorum Fabricius, 1775, the share of which on average accounted for $60 \%$ of all staphylinids. A total of 11 species (Drusilla canaliculata Fabricius, 1787, Oxytelus insecatus Gravenhorst, 1806, Paederus fuscipes Curtis, 1826, Lathrobium laevipenne Heer, 1839, Leptobium gracilis Gravenhorst, 1802, Philonthus fuscipennis Mannerheim, 1830, Ph. varius Paykull, 1789, Ph. scribae Fauvel, 1867, Heterothops dissimilis Gravenhorst, 1802, Tachyporus nitidulus Fabricius 1781, Tachinus discoideus Erichson, 1839, Aleochara laevigata Gyllenhal, 1810) was identified as common, with the share of each equaling $2-5 \%$ of all staphylinids.

Over the vegetative period, the maximum number of staphylinids was seen in late May, with notable decrease in June. In the first half of June, the abundance of beetles fell by over two-four times. In the autumn period, the staphylinids in the wheat fields occurred in single figures or were absent in the catches (Fig. 1).

Among carrion beetles, comprising $2-15 \%$ of the total, we recorded five species, of which only Silpha obscura Linnaeus, 1758 was dominant, and S. carinata Herbst, 1783 and Nicrophorus antennatus Reitter, 1884 were considered common. A high number of carrion beetles was observed in May - early July (2009, 2011), though in some years, they were seen also throughout the spring - summer period, with maximum in the mid summer (2010, Fig. 1, 2). In autumn, no representatives of this family in wheat fields were recorded. The share of skin beetles in different fields and in separate years ranged $2-8 \%$ of the total of all representatives of the suborder. Only two species were recorded, with Dermestes laniarius Illiger, 1801 identified to dominants, and D. kaszabi Kalik, 1950 to subdominants. High activity of the beetles was observed already from the mid May, reaching its peak in the mid June (Fig. 1) or in the first decade of July (Fig. 1, 2). This was due to both biology of development of species and influence of weather conditions.

Ant-like flower beetles (Anthicidae) comprised 3-12\% of the number of all epigean beetles. Within this family, three species were recorded (Anthicus aterrimus Linnaeus, 1760, Formicomis pedestris Rossi, 1790, Hirticollis hispidus Rossi, 1792), which were dominants or subdominants depending on the year and field in which the research was undertaken. The number of ant-like flower beetles was high almost over the entire spring-summer period (Fig. 1). In spring, the beetles occurred frequently, but their abundance at that period was 3-5 times lower than in summer. Maximum activity of beetles was observed in the first half of June (2009, 2011) or first decades of July (2010). In autumn (up to mid October), antlike flower beetles were also frequently recorded in the wheat fields, but their number at that period was 5-6 times lower than in spring and 710 times than in summer.

As for darkling beetles, we recorded 10 species, the total share of which reached $1.5-8.0 \%$ of the total number of epigean beetles. We recorded two abundant species - Crypticus quisquilius Linnaeus, 1761 and Opatrum sabulosum Linnaeus, 1761, while Pedinus femoralis Linnaeus, 1767 and Gonocephalum pusillum Fabricius, 1791 were recorded as common. Their populations significantly varied in different years (Fig. 1,2). In 2008, the peak for those beetles was seen from the late May and almost throughout June, falling by over 5 times in July. In 2009, the number of darkling beetles in May was quite low compared with June, and especially July, and in 2011 high parameters of abundance of the beetles were observed in June (ten times higher than in May and July). In autumn, no representatives of the family were recorded.

Click-beetles were represented by 6 species, which comprised 1.5 $7.0 \%$ of the trapped specimens of the suborder. The dominant species were Aelosomus rossi Germar, 1844 and Agriotes sputator Linnaeus, 1758), while A. gurgistanus Faldermann, 1835 and Melanotus fuscipes Gyllenhal, 1817 were classified to subdominants. The activity of beetles in the wheat fields (similarly to darkling beetles) significantly varied for different years, fields and calendar periods. The highest abundance was more often seen in June and July, but in spring the beetles occurred quite frequently as well (2008, 2011, Fig. 1, 2). However, according to counts in 2009 , the number of click-beetles gradually increased from mid May to mid June and by early July reached its maximum (Fig. 1, 2). In autumn, the beetles were often recorded in September (2008) or recorded singularly $(2009,2011)$. Other beetles which were sporadically observed to be dominants or subdominants were represented mainly by lamellicornbeetles (1.6-12.0\%), weevils (1-4\%), silken fungus beetles (Cryptophagi- 
dae) $(0.5-1.8 \%)$, minute brown scavenger beetles (Latridiidae) $(0.5-$ $4.5 \%)$ and clown beetles $(0.7-2.2 \%$ of all the representatives of the order).
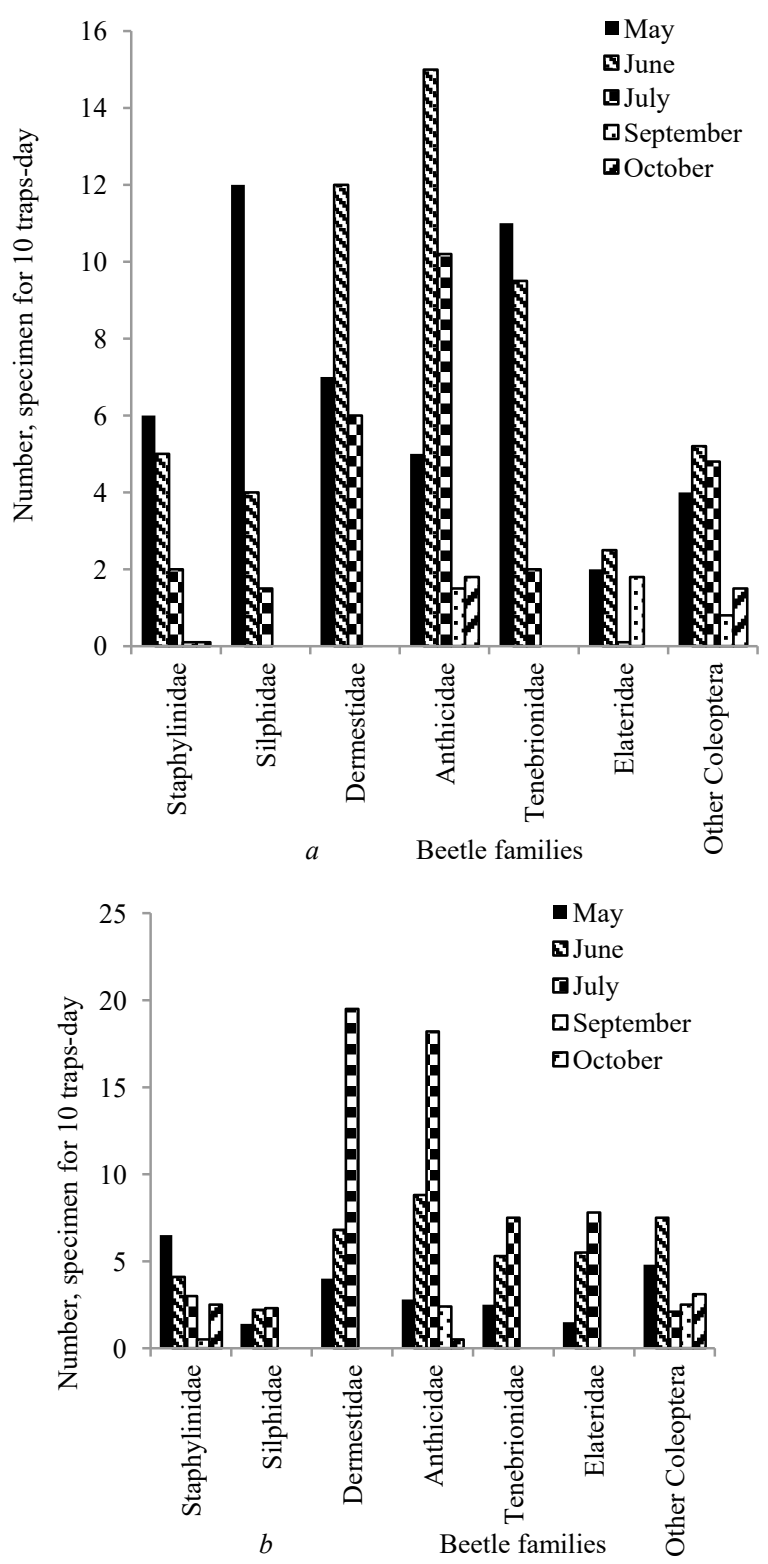

Fig. 1. Changes in the dynamics of density of above-ground beetles in the fields of winter wheat in separate months: $a$ - data for $2008, b$ - data for 2009

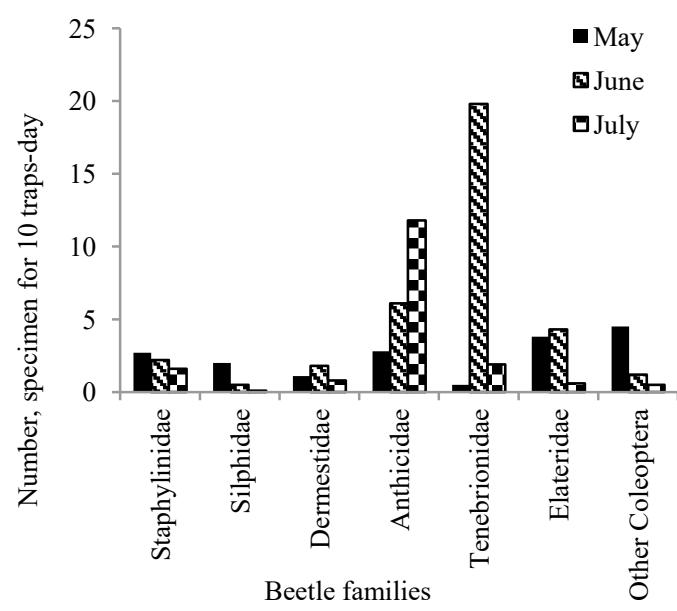

Fig. 2. Changes in the dynamics of density of above-ground coleopterans in the fields of winter wheat for separate months (2011)
As common species in the epigeal habitat, the following may be identified: Aphodius distinctus Muller, 1776, Pleurophorus caesus Creutzer, 1796, Onthophagus vitulus Fabricius, 1776, Pentodon idiota Herbst, 1798 (Scarabaeidae), Gnathoncus suturifer Reitter, 1896, Margarinotus purpurascens Herbst, 1792 (Histeridae), species of genera Latridius, Corticorina (Lantridiidae) and Cryptophagus (Cryptophagidae), Otiorhynchus ligustici Linnaeus, 1758, Psallidium maxillosus Fabricius, 1793 (Curculionidae). Their abundance in some fields of winter wheat diverged broadly in different years, therefore, the peculiarities of changes in the activity of these beetles could not always be determined.

\section{Discussion}

As seen in the quantitative data given above, epigean coleopterans in wheat fields are active and numerous during almost the entire vegetation period of the crop. The pattern and the course of the curve of the total occurrence of beetles in the traps is due to their belonging to various phenological groups, massive emergence or decrease in the number of which to a large extent depends on the vital cycles of the dominant species, their seasonal rhythms of reproduction, and also different activity of imagoes and larvae. This, in turn, is due to the peculiarities of the agrocenosis where the beetles develop and spend most of their life. A certain role in the fluctuation of quantity is often played by weather conditions in different periods of vegetation of the crop. It would be expedient to analyse these patterns regarding the dominant families of coleopterans.
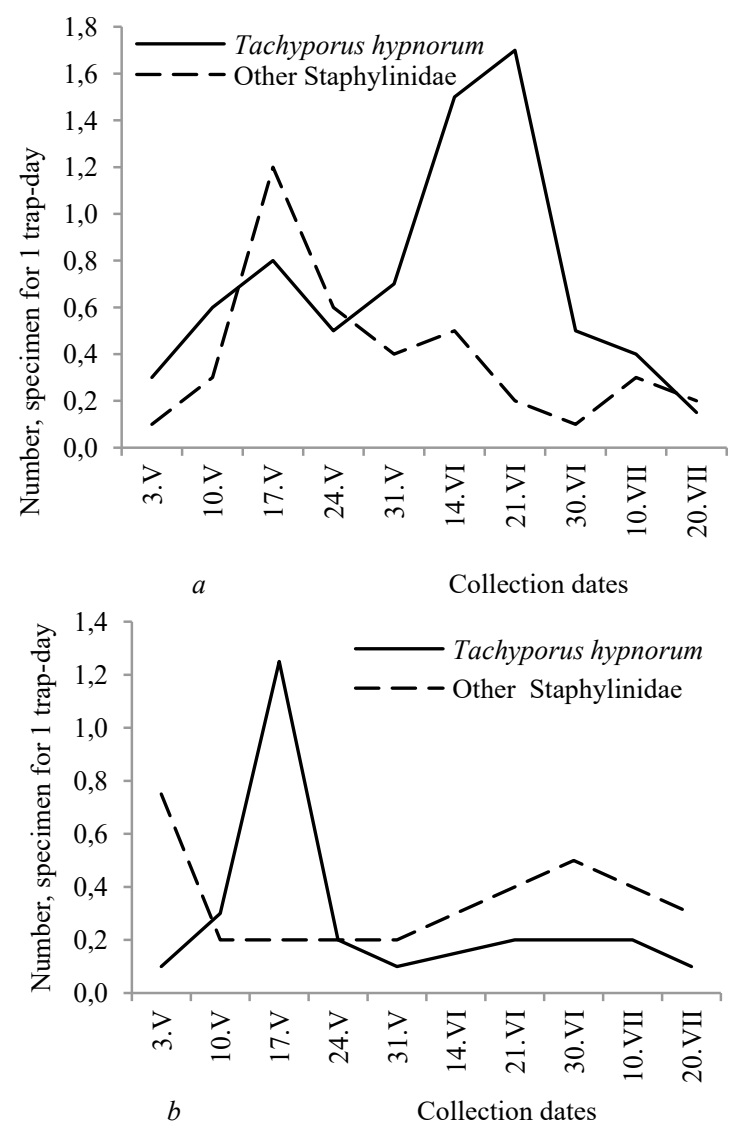

Fig. 3. Seasonal changes in number of staphylinids in fields of winter wheat: $a$ - data for $2008, b$ - data for 2009

Staphylinids. Most staphylinid species recorded in the wheat agrocenosis winter in the stage of imago (Tikhomirova, 1973; Nekulisyanu et al., 1984; Andersen, 1997; Tzurikov, 2016) both directly in the fields of winter wheat and adjoining habitats in the upper soil layers and litter. Emergence of overwintered species is observed already in late March - early April and reaches the highest values in the first half of May. In the late spring, the staphylinids were observed to have the highest abundance and species diversity (late April - beginning of May) compared with other periods of the year. To a high degree, this is related to 
hygropreferendum of these beetles, most of which are mesohygrophilous elements (Tikhomirova, 1973).

Weather conditions of spring characterized by usually heightened moisture compared with the summer period are favourable for life and development of many species in wheat fields. In this period, not only is mass emergence of beetles after winter observed, but also a number of species start to reproduce. Increase in the number of the most numerous species T. hypnorum was also seen in spring, but somewhat later (usually in the II-III decades of May) compared to other species (Fig. 3). Therefore, females of T. hypnorum contained 2-4 eggs in late May, while the sex index equaled 0.50 . Larvae of this species were recorded in wheat fields already in late May, and mass occurrence of them was seen in the first half of June.

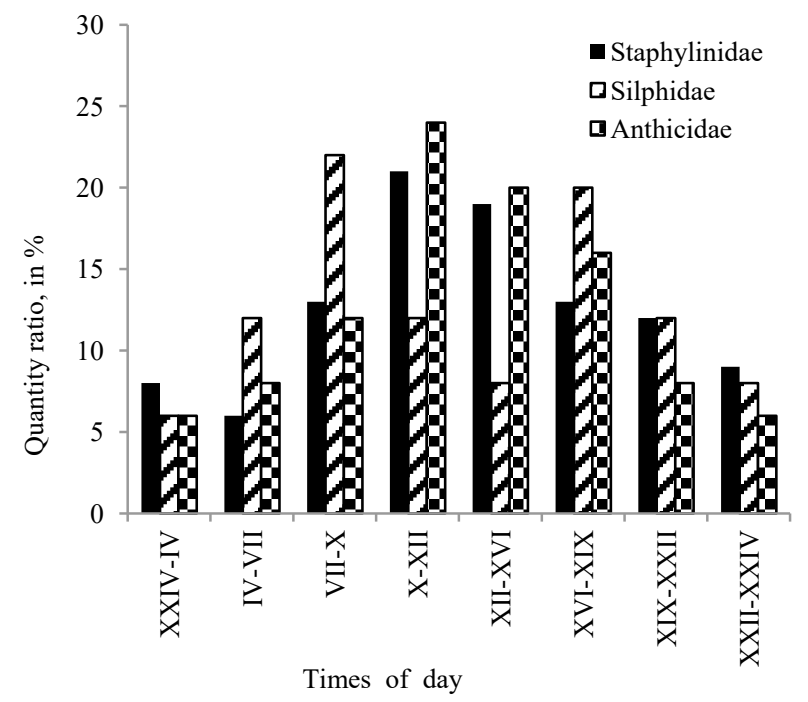

Fig. 4. Changes in the proportion of some coleopterans in a wheat field during $24 \mathrm{~h}$ (data for 2011)

In the summer period, by the end of egg laying, the dynamic density of most species rapidly decreases due to natural death, as well as migration of mesohygrophilous species to other habitats. A similar pattern of changes in the seasonal number of staphylinids was observed in agrocenoses of Zakarpatska Oblast (Bogdanov, 1980), Moldova (Munteanu et al., 2014) and even North-Eastern Russia, but in the latter case in later periods (Guseva \& Koval, 2020).

For most of the recorded species of staphylinids, two or more rarely three generations were characteristic (Tikhomirova, 1973; Nekulisyanu et al., 1987; Andersen, 1997). According to our data, in the wheat fields of the Steppe zone of Ukraine, T. hypnorum has enough time to develop only one generation. Singular emergence of beetles of new generation of this species was observed in late May - early June, but in colder years - in late June. Phenologically this coincides with the phase of booting-ear formation-flowering of wheat. Mass hatching of young beetles was observed in late June - early July, coinciding with the phase of wax ripeness of grain. The low number of staphylinids in autumn is associated with most species entering the wintering phase, but at the same time many species remain in the field. In the conditions of warm weather, catches of small staphylinids were comparatively large until late October.

The rhythmicity of daily activity of most species of staphylinids is not always identified clearly due to the discrete life of these beetles (Tikhomirova, 1973). Their abundance reduced in the morning hours, but was high during the day (Fig. 4), which was more noticeably seen for some species of staphylinids, including the dominant $-T$. hypnorum. This tendency is likely to be associated with the relation of staphylinids to temperature, many of them being megathermophiles (Tikhomirova, 1973).

Carrion beetles. Most species of carrion beetles winter in the phase of imago, chiefly in the litter of windbreak plantations. Their settling in the wheat field was observed already from the second half of April. The peak of abundance of the dominant Silpha obscura was observed in the first half of May, whereas in the summer period (by the end of June or in early July) the abundance of beetles was minimum (around 1 specimen per trapping day, Fig. 5). The period of egg-laying of S. obscura is prolonged and lasts for two months from late April to mid June (Putchkov, 2010). In mid May, 70-80\% of captured females had mature eggs in their gonads, whereas in the early June this parameter decreased by $45-50 \%$. The eggs contained 2-15, more often 4-6 mature eggs, and the share of females in that period reached 0.50-0.55. Larvae of older ages (III-IV), which were typical epigeans, emerged already in late May (phase of booting of wheat), and their highest abundance was observed in late June (phases of tillering-flowering). Imagoes of new generation emerged in early July (phase of wax ripeness), and mass hatching from the pupae was observed in the middle - end of that month (phase of complete ripeness). Most often this occurred already after the harvest, though in some years, young imagoes of $S$. obscura were found in the period of wax-complete ripeness. Maximum of daily activity of imagoes was observed in the latemorning and early-evening hours, but in the day time the beetles were also recorded frequently (Fig. 4)
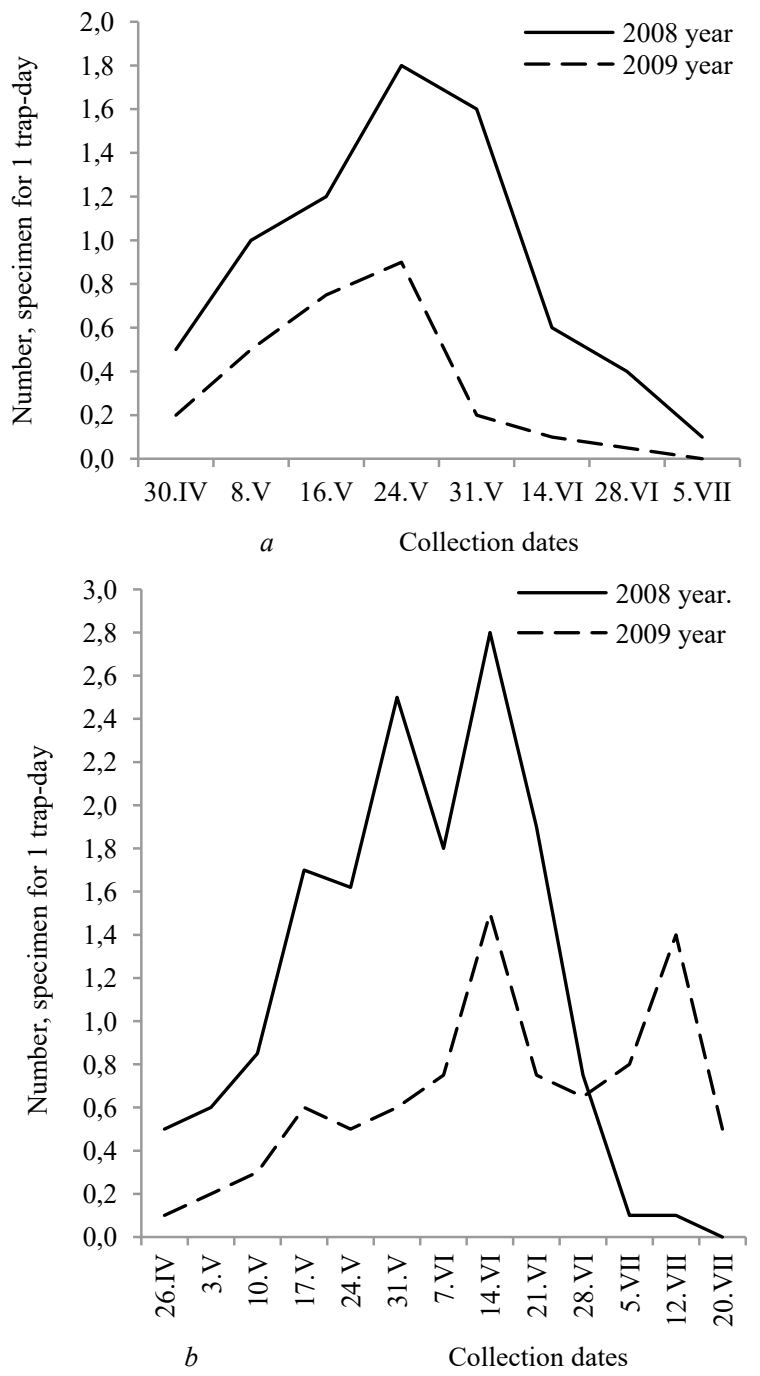

Fig. 5. Seasonal changes in the number of carrion beetles and skin beetles in wheat fields in different years of the research: $a$ - carrion beetles, $b$ - skin beetles

Peculiarities of the development of the related species $S$. carinata are similar to such of $S$. obscura, but increase in the abundance of overwintered imagoes of this species was usually observed somewhat later - in mid - late May (Putchkov, 2010). The species Nicrophorus antennatus was seen more often in May - early June. After the harvest, carrion beetles leave the fields, migrating to windbreaks or crops with longer vegetation (maize, sunflower, perennial herbs), where they often winter. Skin beetles are univoltine species with obligatory imaginal diapause (Zhantiev, 1976; Pushkin, 1999). In the wheat fields, the first wintered beetles were recorded already in late April - early May (Putchkov, 1991) in the conditions 
of average daily temperatures of $+10 \ldots+12^{\circ} \mathrm{C}$. Weather conditions had a significant effect on the activity of skin beetles. In warmer and drier years (2008), the abundance of the beetles was 2-3 times higher than in the years with more moderate weather (Fig. 5). In the conditions of primarily warm weather in spring, imagoes left their wintering sites almost simultaneously, a high number was seen already in late May - early June (usually the end of tillering-flowering phase), and in early July (i.e. in the phase of wax ripeness), individuals were observed occasionally (Fig. 5). However, in the years (2009) with lower average-daily temperature (up to $+11 \ldots+14^{\circ} \mathrm{C}$ in mid May) and more frequent precipitations (up to $90 \mathrm{~mm}$ since mid June), we observed a prolonged period of beetles leaving their wintering sites, significant fluctuations of seasonal activity and a prolonged period of egg deposition. At the same time, differences regarding the phases of vegetation of crop almost coincided, and higher number of skin beetles in the fields was recorded during ear formation - early milk ripeness of grain.

Mating of skin beetles was observed from May to late June, and egglaying - from mid May to late June. Maturation of eggs in the gonads was even, because the share of females with mature production did not exceed $15-20 \%$ in late May - early June. On average, 3-5 mature eggs were recorded. Larvae hatch from the eggs after 5-7 days, and their development (depending on the conditions of environment) lasts for 20-25 to 45 50 days. In the wheat fields, a high number of larvae was recorded from late May to early June (phases of tillering-flowering). Pupation of beetles occurred in the upper layer of soil, and the pupa phase lasts for 12-14 days (Zhantiev, 1976). Singular specimens of imagoes of new generation were seen in the wheat fields in the first days of July. In that period, some combination of the number of young and overwintered imagoes may be observed, as we saw in 2009 (Fig. 5). Mass hatching of imagoes of new generation seems to occur after harvest, but beetles actively migrate to other habitats. In autumn, skin beetles often are seen in wheat fields in September and extremely rarely in October.

Ant-like beetles. Despite the fact that ant-like beetles are constant inhabitants of field crops (Putchkov, 1991; Sumarokov, 2009), the data on their seasonal dynamics are extremely fragmented. These beetles begin to emerge in the wheat fields already in late March - early April. The first to leave wintering sites (fields, sides of roads, windbreaks) are Anthicus antherinus and Formicomus pedestris, whereas the more xerothermophilic Hirticollis hispidus appears 7-10 days later. All the recorded species were characterized by day activity with some increase in the middle of the day (Fig. 4). The first, smaller, rise in the number of antlike beetles in the sowings of wheat was seen in the first half of May and is associated with the reproduction period (Fig. 6). Coupling was observed already in the end of April to mid May. The period of egg deposition is probably prolonged, with females with mature eggs occurring during May-June. Therefore, in mid May, on average the number of mature eggs per one female of H. hispidus was 3.4, and in early June - 2.6, and the gonads contained 6-8, maximum 15 eggs. The sex index reached 0.45 0.53 in the period of maturation and egg-laying, whereas it equalled 0.33 at the beginning of their period of inhabitation of wheat fields.

Young imagoes appeared already in late May - early June (ear formation-flowering), and the highest number of ant-like beetles was recorded in late June, but in some years and in the first decade of July (Fig. 6) it coincided with the phases of milk-wax and wax ripeness of grain. At the same time, as in the period of inhabiting the wheat fields lands, $A$. antherinus and $F$. pedestris emerged earlier with high numbers already observed in the II-III decades of June, while H. hispidus emerged $\mathrm{n}$ late June-early July (Fig. 6).

Abundance and activity of ant-like beetles increased, and their development intensified in warmer and drier years. Therefore, in 2008, the period of spring activity of beetles in the wheat fields was shorter, and mass emerging of young imagoes was seen already starting from the second half of June. In the colder year 2009, the periods of appearance and development of beetles were prolonged, and imagoes of new generation were recorded only beginning from early July, i.e. almost 10-15 days later. However, according to phases of phenology of wheat, emergence of young beetles differed less and corresponded to the phase of milk-wax ripeness of grain. Noticeable decrease in the number of ant-like beetles began directly before the harvest - usually in the first half of July, which is associated with migration of beetles from desiccated wheat fields to other habitats. In autumn (especially September), ant-like beetles were quite common in winter wheat (they also winter there), and their number was not much lower than in the early spring period.

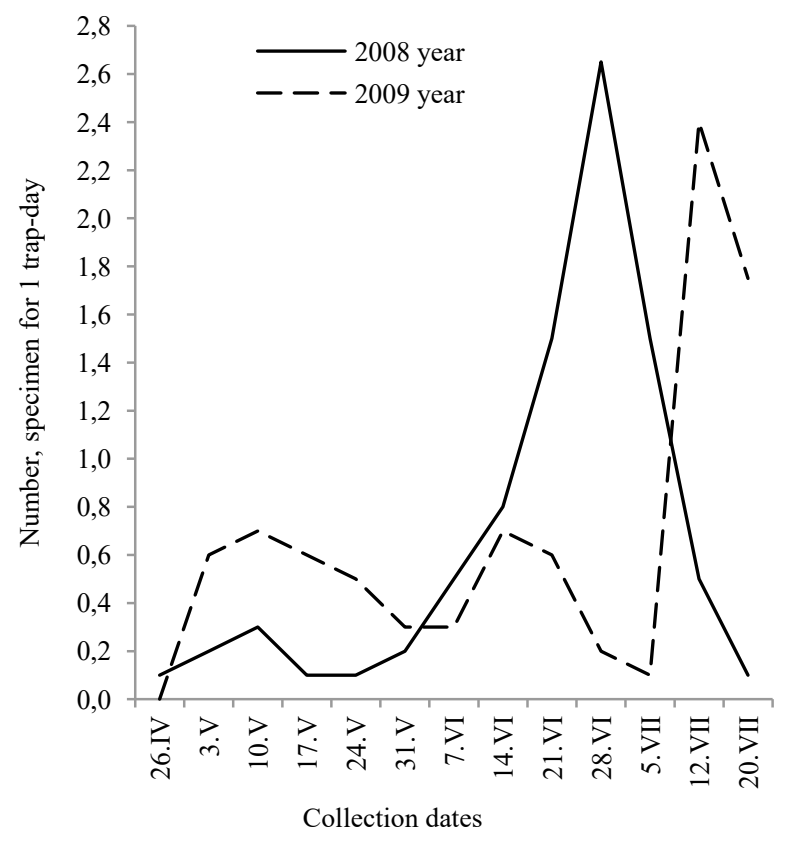

Fig. 6. Seasonal changes in quantity of ant-like beetles in wheat fields in different years of the research

Darkling-beetles. The dominant species Opatrum sabulosum and Gonocephalum pusillum overwinter in the adult phase, Pedinus femoralis - in the stages of imago and larva, and Crypticus quisquilius - only larvae (Cherney, 2005; Brygadyrenko \& Nazimov, 2015). Different life cycles of these species underlie also differences in seasonal dynamics of their abundance in wheat fields in different years.

The spring awakening is related to the emergence of wintered beetles of O. sabulosum and G. pusillum, which began in mid April and reached its maximum in May (Fig. 7). In some years, high abundance of these species was observed throughout May, up until early June, and decrease was seen only in the end of the month. The summer increase in the number of $C$. quisquilius darkling beetles was due to emergence of beetles from pupae, particularly $P$. femoralis. The first individuals of these species were recorded in the first decade of June, and mass appearance was seen after 8-12 days (Fig. 7). Significant decrease in the number of these species was observed in July. In the autumn period, O. sabulosum, G. pusillum and P. femoralis were occasionally found, while $C$. quisquilius was absent.

Click beetles. All species of click beetles recorded in wheat fields overwinter in the stages of imago and larva (Dolin, 1982, 1988). Development of the dominant species Aelosomus rossi and Agriotes sputator lasts - two and 3-5 years respectively. Increase in the number of imagoes of $A$. sputator in wheat fields was recorded from May to mid June, but already at the end of this month, only isolated individuals occurred. Emergence of overwintered beetles of $A$. rossi in the fields was recorded already from mid April. Seasonal dynamics of the abundance of this species were characterized by gradual increase throughout May, with a peak at the end of the month and early June (Fig. 7).

At the same time, if the spring increase occurred gradually, the summer increase was more notable in more humid years (2009). We can presume that reproduction of $A$. rossi in wheat fields is sporadic, only in the conditions favourable for the development of larvae. In autumn, imagoes of $A$. rossi, unlike $A$. sputator, were common in the wheat fields, but their abundance was significantly lower than in spring. Different dynamics of emergence of these two dominant species in wheat sowings underlie also the differences in increase-decrease in the number of click beetles in general during a season and depending on the year (Fig. 7). 

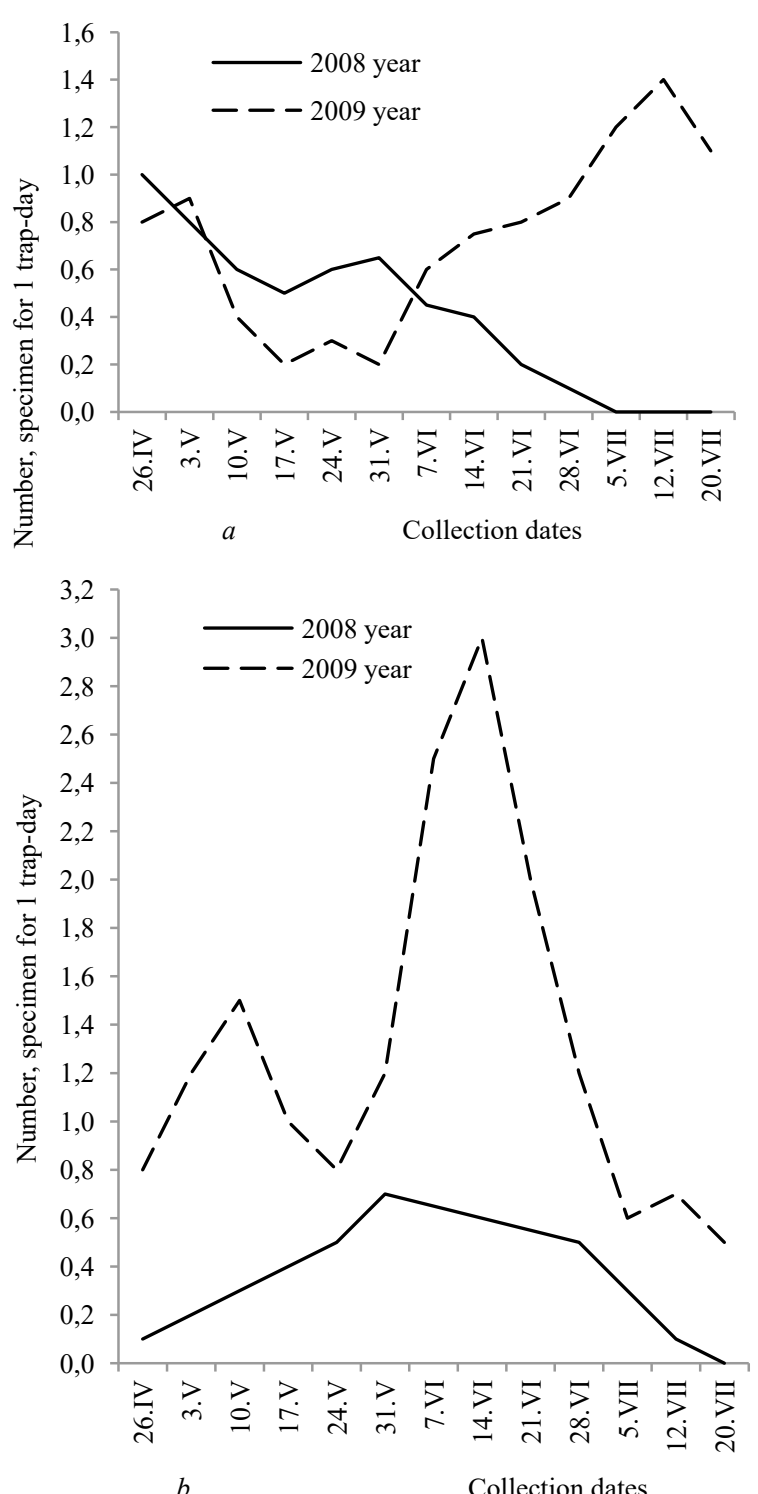

Fig. 7. Seasonal changes in the abundance of darkling beetles and click beetles in wheat fields in different years of the survey: $a$-darkling beetles, $b$ - click beetles

Other epigean beetles of the Polyphaga suborder. The surveys revealed quite a high number of other epigean beetles in wheat fields almost throughout the vegetation period (Fig. 1), which is due to the varying phenology and way of life of the species occurring. At the same time, abundance of each species of the certain families was low.

Among lamellicom-beetles, emergence of the dominant species Pentodon idiota was recorded in mid May, and increase in its abundance was observed in late spring-early summer, i.e. in the period of egg deposition. However, already since July, these beetles occurred rarely, and were not found in autumn. Most of the representatives of the Geotrupinae subfamily (species from the Aphodius, Onthophagus, Pleurophorus genera) occurred in the wheat fields earlier - already in mid April. High abundance of $P$. caesus was recorded from April to mid May, but mating individuals were observed in early May. However, the number of females with mature eggs was low (around 10\%). In the gonads of females, 3-5 eggs were found, and the sex ratio was practically 1:1. By the end of spring, the abundance of $P$. caesus rapidly decreased and in June the species was recorded singularly. In the autumn period, among lamellicorn beetles, in the wheat fields, only Aphodius distinctus was occasionally seen.

Clown beetles (mostly Margarinotus purpurascens) were recorded in wheat fields more often in spring, and the highest abundance of these beetles was observed during May. At the same time, Gnathoncus suturifer was more often observed in the first half of summer. Also in spring, as subdominants some above-ground species of weevils were recorded (Otiorhynchus ligustici, Psalidiuum maxillosum) and pill-beetles (Byrrhidae).

Minute brown scavenger beetles (Latridiidae) and silken fungus beetles (Cryptophagidae) were usually observed to have two peaks of abundance: in the first half of May and the second one in the second half of June. At the same time, in summer, young beetles which had just hatched from the pupae occurred more often. In autumn (September - early October) some silken fungus beetles were seen, while no minute brown scavenger beetles were found in the period.

\section{Conclusion}

In total, in the fields of winter wheat, 168 species of beetles of 25 families of Polyphaga suborder were recorded. A total of 116 species were identified to herpetobionts, including 14 dominants, 32 subdominants and about 70 species were rare or occurred singularly. The main representatives of the epigean beetles were staphylinids, carrion-beetles, skin beetles, clown beetles, ant-like flower beetles, minute scavenger beetles, silken fungus beetles, some click beetles, lamellicorn beetles and most darkling beetles.

Most staphylinids were abundant in spring (late April - first half of May). In summer, for some species (Tachyporus hypnorum), the second peak in abundance is possible due to the emergence of beetles of new generation. A high number of carrion beetles was seen by mid May, but they decreased in the summer months, and mass emergence of young beetles was seen in midsummer. Ant-like flower beetles, minute scavenger-beetles, silken fungus beetles were characteristic of two peaks in abundance: the lesser one in spring (first half of May) and the greater in summer (second half of June - early July). The abundance of skin beetles increased gradually from mid May and reached maximum values at the end of the month - beginning or middle of June. Among darkling beetles, species of Opatrum and Gonocephalum genera were more abundant in spring than in summer, but in Crypticus quisquilius, the peak of activity was observed in midsummer. In click beetles, the increase in the number of Agriotes sputator was recorded from May to mid June, and emergence of Aelosomus rossi was recorded from mid April, but with peak of abundance in the first half of summer. In spring, more often than in summer, lamellicom beetles (Geotrupinae), clown beetles and some species of weevils were seen.

In years with different meteorological conditions, significant differences were recorded for calendar periods of rise and fall in numbers of many beetles. Lower differences of fluctuations of abundance were observed by comparison with phases of vegetation of wheat. Some peculiarities of the dynamics of sex index (increasing by the period of egg laying) and development of dominant species were considered briefly.

The authors are very grateful to the Prof. of the I. I. Schmalhausen Institute of Zoology of National Academy of Sciences of Ukraine (Kyiv) A. V. Puchkov for numerous consultations and check of identifications of a number of species of beetles. Special acknowledgement to the employees of the Department of Entomology and Scientific Fund Collections of the I. I. Schmalhausen Institute of Zoology of National Academy of Sciences of Ukraine (Kyiv), Ph.D. L. S. Chernei (darkling beetles) for the invaluable help in identification of the material.

\section{References}

Andersen, A. (1997). Densities of overwintering carabids and staphylinids (Coleoptera, Carabidae and Staphylinidae) in cereal and grass fields and their boundaries. Journal of Applied Entomology, 121(2), 77-80.

Belitzkaya, M. N. (2015). Kolebanie sostava i chislennosti entomofauny v lesozaschischennyikh agrotsenozakh [Fluctuations in the composition cnd abundance of entomofauna in the forest-protected agrocenoses]. Vestnik of Volgograd State University, 1(11), 52-60.

Bogdanov, Y. A. (1980). K izucheniyu stafilinid (Coleoptera, Staphylinidae) na pzhenichnykh polyakh Zakarpatiya [To the study of staphylinids (Coleoptera, Staphylinidae) on the wheat fields of Transcarpathia]. In: Entomophagous and pest insects. Shtiintza, Kishinev. Pp. 3-6 (in Russian). 
Brygadyrenko, V. V. (2014). Influence of soil moisture on litter invertebrate community structure of pine forests of the steppe zone of Ukraine. Folia Oecologica, 41(1), 8-16.

Brygadyrenko, V. V. (2016). Effect of canopy density on litter invertebrate community structure in pine forests. Ekológia (Bratislava), 35(1), 90-102.

Brygadyrenko, V. V., \& Nazimov, S. S. (2015). Trophic relations of Opatrum sabulosum (Coleoptera, Tenebrionidae) with leaves of cultivated and uncultivated species of herbaceous plants under laboratory conditions. Zookeys, 481, $57-68$.

Chemey, L. S. (2005). Zhuki-chernotelki (Coleoptera, Tenebrionidae). Fauna Ukrainy [Darkling beetles (Coleoptera, Tenebrionidae). Fauna of Ukraine]. Vol. 19(10). Naukova Dumka, Kiev (in Russian).

Cloyd, R. A., \& Herrick, N. J. (2018). Effects of pesticides on the survival of rove beetle (Coleoptera: Staphylinidae) and insidious flower bug (Hemiptera: Anthocoridae) adults. Journal of Economic Entomology, 111, 78-88.

Dolin, V. G. (1982). Zhuky-kovalyki: Agripnini, Negastrerini, Dimini, Atoiini, Estodini. Fauna Ukrayiny [Click-beetles: Agripini, Negastreni, Dimini, Atoini, Estodini (Fauna of Ukraine]. Vol. 19(3). Naukova Dumka, Kyiv (in Ukranian).

Dolin, V. G. (1988). Zhuki-schelkuny. Kardioforinyi i Elaterinyi. Fauna Ukrainy [Clickbeetles. Cardiophorini and Elaterini. Fauna of Ukraine]. Vol. 19(3). Naukova Dumka, Kiev (in Russian).

Frank, T., \& Reichhart, B. (2004). Staphylinidae and Carabidae overwintering in wheat and sown wildflower areas of different age. Bulletin of Entomological Research, 94, 209-217.

Gospodarek, J., Boligłowa, E., \& Gleń-Karolczyk, K. (2020). Impact of nonchemical nrotection of broad bean on epigeic and soil arthropodofauna - Analysis in field-realistic conditions. Agronomy, 10(2), 211.

Guseva, O. G. (2019). Investigation of biodiversity and distribution of rove beetles (Coleoptera, Staphylinidae) in the agrolandscape in Northwestern Russia. Acta Biologica Sibirica, 5(1), 12-18.

Guseva, O. G., \& Koval, A. G. (2011). Regionalnoe rasprostranenie Carabidae i Staphylinidae v agroekosisteme [Regional distribution of Carabidae and Staphylinidae in agroecosystem]. Agricultural Biology, 1, 118-123 (in Russian).

Guseva, O. G., \& Koval, A. G. (2015). Influence of soddy-podzolic soil improvement on the abundance and structure of complexes of epigeic predatory beetles (Coleoptera: Carabidae, Staphylinidae) in Northwestern Russia. Entomological Review, 95(8), 1051-1060.

Guseva, O. G., \& Koval, A. G. (2020). The distribution of the surface-active beetles (Coleoptera: Carabidae, Staphylinidae, Elateridae) in the agricultural landscapes of Northwestern Russia. BIO Web of Conferences 18, 00014.

Hummel, R. L., Walgenbach, J. F., Hoyt, G. D., \& Kennedy, G. G. (2002). Effects of vegetable production system on epigeal arthropod populations. Agriculture, Ecosystems and Environment, 93, 177-188.

Komaromi, N. A., Nikolenko, N. Y., \& Putchkov, A. V. (2018). The faunistic structure of the beetles (Insecta: Coleoptera) in the herpetobios of urbocenoses of Kharkov [Faunisticheskiy sostav zhestkokrylykh (Insecta: Coleoptera) herpetobiya urbotsenozov g. Kharkova]. Ukrainian Entomological Journal, 15(2), 3-21 (in Russian).

Komaromi, N. A., Putchkov, A. V., \& Nazarenko, V. Y. (2019). Peculiarities of seasonal changes in taxonomic structure and number of weevil-beetles (Coleoptera, Curculionidae) in the herpetobios of urbocenoses of Kharkiv (Ukraine) [Osobennosti sezonnykh izmeneniy taksonomicheskoy struktury i chislennosti zhukov-dolgonosikov (Coleoptera, Curculionidae) herpetobiya urbotsenozov g. Kharkova (Ukraina)]. Ukrainian Entomological Journal, 16(1), 25-35 (in Russian).

Munteanu, N., Bacal, S., Moldovan, A., Malevanciuc, N., \& Toderas, I. (2014). Beetle communities of alfalfa (Medicago sativa L.) in the Republic of Moldova APCBEE Procedia, 8, 21-26.

Nekulisyanu, Z. Z., Ostafichuk, V. G., \& Tsygankova, A. F. (1987). Biologicheskie osobennosti nekotorykh vidov stafilinid roda Philonthus Curt. (Coleoptera,
Staphylinidae) fauny Moldavii [Biological features of some species of staphylinids of the genus Philonthus Curt. (Coleoptera, Staphylinidae) in Moldova]. Entomological Review, 66(3), 511-518.

Pushkin, S. V. (1999). Zhuki-necrophagi v ecosistemakh Stavropolskoi vosvyshennosti. Semejstva Slphidae, Dermestidae, Trogidae, Catopidae [Necrophagous beetles in ecosystems of the Stavropol upland. Families Silphidae, Dermestidae, Trogidae, Catopidae]. Stavropol' State University, Stavropol' (in Russian).

Pushkin, S. V. (2010). Nekrofilnye zhestkokryilyie yuga Rossii [Necrophilous beetles of the Southern Russia]. Stavropol' State University, Stavropol' (in Russian).

Putchkov A. V. (1985). K ekologii kozheedov (Coleoptera, Dermestidae) ozimoy pshenitsy yuga stepnoy zony USSR [On the ecology of skin-eater beetles (Coleoptera, Dermestidae) of winter wheat in the south of steppe zone of the Ukrainian SSR]. Vestnik Zoologii, 1, 75-76 (in Russian).

Putchkov, A. V. (1991). Zhestkokylye (Coleoptera) pshenichnykh polei yugo-zapada Evropeiskoj chasti SSSR [The beetles (Coleoptera) of the wheat fields of the southwest of the steppe zone of the European part of the USSR]. Entomological Review, 3, 538-549 (in Russian).

Putchkov, A. V. (2010). Zhuki-mertvoedy (Coleoptera, Silphidae) agrotsenozov Ukrainy [Carrion beetles (Coleoptera, Silphidae) of agrocenoses of Ukraine]. Ukrainian Journal of Entomology, 1(1), 71-79 (in Russian).

Putchkov, A. V. (2018). Zhuki-zhuzhelitsyi (Coleoptera, Carabidae) transformirovannykh tzenozov Ukrainy [The ground-beetles (Coleoptera, Carabidae) of transformed cenoses of Ukraine]. Kiev (in Russian).

Putchkov, A. V., \& Komaromi, N. A. (2018). Zhuki-karapuziki (Coleoptera, Histeridae) urbotsenozov Kharkova (Ukraina) [The clown beetles (Coleoptera, Histeridae) of the urbocenosises of Kharkiv city (Ukraine)]. Biology and Valeology, 20, 54-58 (in Russian).

Putchkov, A. V., Brygadyrenko, V. V., \& Markina, T. Y. (2019). Ground beetles of the tribe Carabini (Coleoptera, Carabidae) in the main megapolises of Ukraine. Vestnik Zoologii, 53(1), 3-12.

Růžička, J. (1994). Seasonal activity and habitat associations of Silphidae and Leodidae: Cholevinae (Coleoptera) in Central Bohemia. Acta Societatis Zoologicae Bohemicae, 58, 67-78.

Skoková-Habužstová, O., Svobodová, Z., Spitzer, L., Doležal, P., Hussein, H. M., \& Sehnal, F. (2014). Communities of ground-dwelling arthropods in conventional and transgenic maize: Background data for the post-market environmental monitoring. Journal of Applied Entomology, 139, 21-45.

Soboleva-Dokuchaeva, I. I., Tshernyshev, W. B., Afonina, V. M., \& Timokhov, A. V. (2002). Sezonnaya dinamika prostranstvennogo raspredeleniya massovyih zhukov-stafilinid (Coleoptera, Staphylinidae) v agroekosistemah [Seasonal dynamics of spatial distribution of mass staphylinid-beetles (Coleoptera, Staphylinidae) in agroecosystems]. Journal of Zoology, 81(4), 451-456 (in Russian).

Sumarokov, A. S. (2009). Vosstanovlenie bioticheskogo potentsiala biogeotsenozov pri izmenenii pestitsidnykh naguzok [Rehabilitation of the biotic potential of biocenoses with a decrease of the pesticide loads]. Weber, Donetsk (in Russian).

Tikhomirova, A. L. (1973). Morfoekologicheskie osobennosti i filogenez stafilinid (s katalogom faunyi SSSR i sopredelnyih territoriy) [Morphological and ecological features and phylogenesis of staphylinids (with a catalogue of fauna of USSR and adjacent territories)]. Nauka, Moscow (in Russian).

Tikhomirova, A. L. (1975). Uchet napochvennykh bezpozvonochnykh [Registration of soil invertebrates]. In: Methods of soil and zoological researches. Nauka, Moscow. Pp. 73-86 (in Russian).

Tzurikov, M. N. (2016). Osobennosti grupp imago Coleoptera (Insecta), zimuyuschih v raznyih substratah na territorii zapovednika "Galichya gora" [Peculiarities of Coleoptera (Insecta) adult groups wintering in different substrates on the territory of the "Galichya Gora"]. Zapovednaya Nauka, 1(1), $52-64$ (in Russian).

Zhantiev, R. D. (1976). Zhuki-kozheedy fauny SSSR [Skin beetles of USSR fauna]. Moscow State University, Moscow (in Russian). 